\title{
Saccharomyces hienipiensis, a New Melibiose-fermenting Yeast, Unable to Assimilate Raffinose
}

\author{
BY J. SANTA MARIA \\ Sección de Bioquímica Instituto Nacional de Investigaciones Agronómicas \\ Madrid 3, Spain \\ (Received 5 September 1961) \\ SUMMARY
}

A new Saccharomyces species has been isolated from 'alpechin'. It is distinguished from other species of the genus by its ability to ferment and assimilate glucose, maltose and melibiose. Galactose, sucrose, lactose and raffinose are not assimilated. The melibiase found in $S$. hienipiensis can hydrolyse raffinose.

\section{INTRODUCTION}

A new melibiose-fermenting yeast has been isolated from 'alpechin' (aqueous solution separated during the manufacture of olive oil), which apparently cannot be identified with previously described species. I propose to name the new yeast by the latin name (Hienipa) of Alcalá de Guadaira, the village in the south of Spain (Sevilla) from which the first strain was obtained.

\section{METHODS AND RESULTS}

Origin of the strain. Two strains were studied, both isolated from 'alpechin' received in December 1959 from Alcalá de Guadaira, Sevilla, Spain. The isolations were effected by streaking the alpechin directly on potato glucose agar (Difco) acidified to $\mathrm{pH} 3.5$ with sterile tartaric acid $(10 \%$, w/v solution) after sterilization.

Methods. The characters were examined by the methods of Lodder \& Kregervan $\mathrm{Rij}$ (1952), with some exceptions as regards the procedure for studying sugar assimilation. For these latter tests the method of Wickerham (1951) was followed, as well as for the vitamin deficiency tests, growth at moderate osmotic pressure, etc.

\section{Description of Saccharomyces hienipiensis}

Growth on malt extract. After 3 days at $25^{\circ}$ cells are oval to long oval $2 \cdot 6-6 \cdot 5 \times 3.9$ 14.5 $\mu$, occurring singly. A sediment is formed (Fig. 1).

On malt agar the streak after 1 month is filiform, cream coloured, soft, smooth and shining. Margin smooth.

Slide culture. No pseudomycelium is formed.

Sporulation. In MA 29 sporulation medium (Santa Maria, 1959; MA 29 sporulation medium $=$ Kleyn medium $($ Kleyn, 1954) $+0 \cdot 1 \%$, w/v DL-serine, British Drug Houses Ltd.), spores are formed moderately after 7 days of incubation at $\mathbf{2 5}^{\circ}$; 1-4 spores per ascus (Fig. 2). The spores are round or oval and have a smooth surface. No cases of conjugation were observed before spore formation, but only partheno- 
genetic production of asci. Yet, isogamous or heterogamous conjugation of cells, without spores, were sometimes observed. The asci do not rupture at maturity.

Fermentation. Glucose + ; maltose + ; melibiose + ; galactose- ; sucrose- ; lactose - ; raffinose - .

Fermentative power: After 1:) days of anaerobic incubation at $25^{\circ}$, yeast water with $13.6 \%(\mathrm{w} / \mathrm{v})$ glucose is fermented and the ethanol produced is $8 \cdot 9 \%(\mathrm{w} / \mathrm{v})$.

Assimilation. Glucose, maltose, trehalose, melibiose and pyruvic acid (latent and weak) are assimilated. Compounds not assimilated: galactose, L-sorbose, sucrose, cellobiose, lactose, raffinose, mele zitose, inulin, soluble starch, D-xylose, L-arabinose, D-arabinose, D-ribose, L-rhamnose, D-glucosamine hydrochloride, ethanol, glycerol, i-erythritol, adonitol, dulcitol, D-mannitol, D-sorbitol, alpha-methyl-D-glucoside, salicin, DL-lactic acid, succinic asid, citric acid, ethyl acetoacetate, i-inositol.

Assimilation of $\mathrm{KNO}_{3}$. Negative.

Growth in a vilamin-free medium. None.

Growth in the osmotic pressure medium. None

Growth at $37^{\circ}$. Positive.

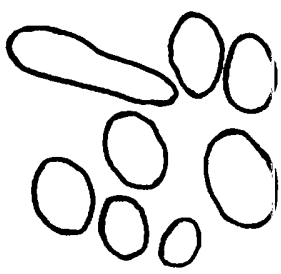

Fig. 1

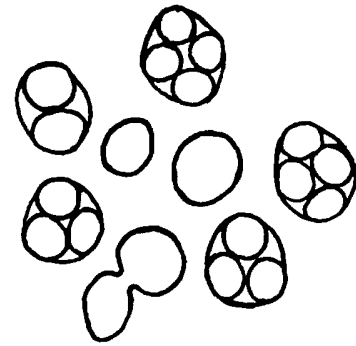

Fig. 2

Fig. 1. Saccharomyces hienipiensis sp.nov. After 3 days in malt extract medium at $25^{\circ} . \times 2000$.

Fig. 2. Saccharomyces hienipiensis sp. nov. Ascospores on MA 29 sporulation medium after 7 days at $25^{\circ} . \times 2000$.

The strains studied must und oubtedly be included in the genus Saccharomyces, given their general characteristic (method of vegetative reproduction, non-formation of pellicle, non-assimilation of $\mathrm{KNO}_{3}$ ) and their capacity for fermentation. Up to the present, no species is known in this genus whose biochemical characteristics for fermentation and assimilation correspond to those described here; therefore it would seem that these strains ought to be considered as a new species.

Until Van Uden \& Assis-Lopes (1957) described Saccharomyces italicus var. melibiosi, no yeast was known $w$.th the ability to ferment raffinose but not sucrose. Later Santa Maria (1958) described a new species, $S$. oleaginosus, with a similar biochemical spectrum. A comparative study of these two yeasts awaits publication. The species here described is a yeast capable of fermenting melibiose but which neither ferments nor assimilates sucrose or raffinose.

To test the action of the melib ase of this yeast on raffinose, the residual sugars in the assimilation tubes were identified chromatographically, by the following paper 
chromatographic technique. The descending method was used, with development for $48 \mathrm{hr}$. with solvent $n$-butanol + acetic acid + water $(4+1+5$ by vol. $)$ on Schleicher 2040 A paper. The papers after drying were sprayed with aniline hydrogen phthalate for aldohexoses and with urea solution for hexuloses, and heated at $105^{\circ}$ for $10 \mathrm{~min}$.

The normal test-tubes for assimilation of melibiose and raffinose were examined chromatographically after 21 days of incubation. The sugar present in the melibiose tube was galactose; and in the raffinose tube was raffinose. Because of this result, two assimilation tubes with melibiose and raffinose, respectively, were each inoculated with growth from the whole of a streak of 48-hr. growth on a malt agar slope. The sugar tubes were incubated for 11 days; then by chromatography it was found that the residual sugars were: in the melibiose tube, galactose; and in the raffinose tube, raffinose, sucrose and galactose. Finally, sterile glucose $0 \cdot 1 \%(\mathrm{w} / \mathrm{v})$ was added to the raffinose assimilation tubes which were inoculated in the usual way and incubated for 21 days at $\mathbf{2 5}^{\circ}$. The residual sugars in this case were also raffinose, sucrose and galactose.

It seems, therefore, that the melibiase of Saccharomyces hienipiensis is a constitutive enzyme capable of hydrolysing the raffinose to sucrose and galactose. The negative result obtained in the normal raffinose tubes was undoubtedly due to the fact that few organisms inoculated were incapable of development, as they had no assimilable carbon source and their ability to hydrolyse raffinose was not sufficient to be shown by chromatography. When the amount of cellular material was increased, either by direct addition or by stimulating its development in presence of raffinose, a clear hydrolysis was produced.

We are of the opinion, therefore, that Saccharomyces hienipiensis is not only a new species, but may also elucidate points in the genetics of the fermentation of melibiose (Roberts, Ganesan \& Haupt, 1959).

One of the two strains of Saccharomyces hienipiensis has been chosen as the type of the species and is maintained under reference no. Le Ac 132, in the culture collection of the Sección de Bioquímica, Instituto Nacional de Investigaciones Agronómicas, Madrid. A subculture has been deposited in the Yeast Collection of the Centraal Bureau voor Schimmelcultures in Delft.

\section{Latin diagnosis}

\section{Saccharomyces hienipiensis, sp.nov.}

In musto maltato cellulae ovoideae aut long ovoideae $2 \cdot 6-6 \cdot 5 \times 3 \cdot 9-14.5 \mu$, singulae. Sedimentum formantur.

In agaro maltato cultura (post unum mensem, $17^{\circ}$ ) mollis, glabra, nitida, flavalbida. Margine glabro.

Pseudomycelium nullum.

Asci formantur ex transformatione cellularum vegetativarum diploidearum; ascosporae rotundae aut ovoideae; 1-4 in asco.

Glucosum, maltosum et melibiosum fermentatur at non galactosum, saccharosum, lactosum et raffinosum.

In medio minerali glucosum, maltosum, trehalosum, melibiosum et acidum pyruvicum (exiguum) assimilantur, at non galactosum, sorbosum, saccharosum, cellobiosum, lactosum, raffinosum, melezitosum, inulinum, amylum solubilis, 
xylosum, arabinosum, ribosum, rhamnosum, alcohole aethylicum, erythritolum, adonitolum, dulcitolum, manni olum, sorbitolum, alpha-methyl-glucosidum, salicinum, acidum lacticum, acicum succinicum, acidum citricum, acetoacetate aethylicum et inositolum.

Nitras kalicus non assimilatur.

Necessariae ad crescentiam sunt vitamina externae.

Isolate ex amurca in Alcalá de Guadaira (Sevilla, España).

This paper is published by permission of the President of the Instituto Nacional de Investigaciones Agronómicas Madrid.

\section{REFERENCES}

KLEYN, J. G. (1954). A study of some environmental factors controlling sporulation of yeasts using a new sporulation medium. Wallerstein Labs. Commun. 17, 91.

Lodder, J. \& Kreger van-RiJ, N. J. W. (1952). The Yeasts. A Taxonomic Study. Amsterdam: North Holland Publishing Co.

Roberts, S., Ganesan, A. T. \& H H.UpT, W. (1959). Genetics of melibiose fermentation in Saccharomyces italicus var. melibiosi. Heredity, 13, 499.

Santa Maria, J. (1958). Ecología de las levaduras. I. Nuevas especies aisladas de 'alpechín'. Bol. Inst. Invest. agrom. Madr. 38, 301.

Santa Maria, J. (1959). Poliploidía en Saccharomyces. An. Inst. Nac. Invest Agron, Madr. 8, 681.

VAN Uden, N. \& Assis-Lopes, L. (1957). Fermentation of raffinose in the absence of invertase by Saccharomyces italicus Castelli var. melibiosi nov. var. Port. Acta biol. 4 (Ser. A), 323.

Wickerham, L. J. (1951). Taxonomy of Yeasts. Tech. Bull. U.S. Dep. Agric. no. 1029. 